\title{
Impact of Biocide, Insecticides, Compost and Mineral Fertilizers Treatments on the Abundance of Parasitoid and Predator Insects in Rice Fields El-Sheikh, M. F. ${ }^{1}$; F. H. Hegazy ${ }^{1}$ and A. S. Hendawy ${ }^{2}$ \\ ${ }^{1}$ Department of Plant Protection, Faculty of Agriculture, Tanta University, Egypt. \\ 2 Biological Control Research Department, Plant Protection Research Institute,Agricultural Research, Center, Giza, Egypt.
}

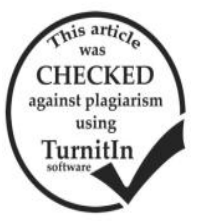

\section{ABSTRACT}

The present study was designed to investigate the effect of rice straw compost, recommended mineral fertilizers, Organic Insecticides and chemical Insecticides on the abundance pattern of natural enemies in rice ecosystems. To maximize rice productivity, rice growers tend to use chemical fertilizers and pesticides particularly to control different pest species, regardless of damage levels. Accordingly, rice fauna of natural enemies is severely impaired, leading to unbalanced rice ecosystems. The current investigation was carried out at the experimental farm of Rice Research and Training Center (RRTC), Sakha, Kafr El-Sheikh during 2016 and 2017 rice seasons. Using both D-Vac machine and pit-fall traps, parasitoids and predator insects were surveyed. Twelve hymenopterous parasitoid species were surveyed. Most of the parasitoid species were found belonging to Mymaridae, Trichogrammatidae and Braconidae. Twenty insect predator species, related to 13 families and seven orders, were identified, most of which are belonging to Coleoptera and Hymenoptera. Also this study aimed to surveying natural enemies (parasitoids and predator insects) and the effect of compost as an organic fertilizer on population densities of such beneficial insects. Although the application of insecticides successfully controlled insect pests, these chemicals have almost eradicated (more than $90 \%$ reduction) the natural enemies. Biocide applications, especially Achook (Neem) and Tracer, achieved a considerable insect pest control, with population reductions of 33.30-57.32 and 10$46.01 \%$, respectively. Unfortunately, the evaluated biocides induced mortalities to the considered natural enemies, but with too much less levels than did the insecticides. The current results indicate that the biocides could be applied to control rice insects in case of moderate insect infestations, with taking into consideration that they are not completely safe to the beneficial insects.

Keywords: Rice field, Parasitoids, Predators, Compost, Biocide, Insecticides.

\section{INTRODUCTION}

Rice (Oryza sativa, L.) is considered as one of two most important cereal crops in the world. In Egypt, it contributes more than 20 percent of the cereal consumption. Organic fertilizers and insecticides are systems in which primarily aimed to eliminate environmental pollution and develop a more profitable and sustainable farming ( $Y u n g Y u$, 2005, Heckman, 2006 and Badr, 2008).

Instead of burning of rice straw by farmers after harvesting, there are other economical ways to get rid of it as making compost and incorporation into the soil as a source of organic matter (Gotoh et al.1984).

Irrigated rice fields, being agronomically managed wetland ecosystems with a high degree of environmental heterogeneity operating on a short temporal scale, harbour a rich and varied fauna (Heckman, 1979). The fauna is dominated by micro, meso and macro invertebrates (especially arthropods) inhabiting the soil, water and vegetation sub-habitats of the rice fields. The terrestrial arthropod community in rice fields consists mainly of insects which largely inhabit the vegetation (rice plants and weeds), and the soil surface. The occurrence of terrestrial arthropods in the rice ecosystem is mainly influenced by the rice plants. The different communities of terrestrial arthropods in the rice field include rice pests, their natural enemies (predators and parasitoids) and other non-rice pest insects that inhabit or visit the vegetation. The composition of the arthropod communities is known to change with the growth of the rice crop (Heong et al., 1991).

Parasitoids and predator insects have an important role in managing rice insect pests. Thus, these beneficial arthropods constitute an essential part of integrated pest management system.

Egg parasitoids such as Trichogramma spp. have been widely utilized as biocontrol agents (Bigler 1986, Abbas, 1998, Anonymous, 2002). In Egypt, release of Trichogramma evanescens West. achieved a good control to the rice stem borer, Chilo agamemnon Bles. ( Soliman and
Ewaise, 1997 and Sherif et al. 2008). The leaf and planthopper egg parasitoids; Oligosita sp. (Trichogrammatidae) and Anagrus sp. (Mymaridae) performed 29-91\% control of brown planthoppes (Claridge et al. 1999) also these parasitoids attacked many leafhoppers and planthoppers eggs in Egypt (Hendawy, 2001). Insect predators, mainly Ischnura senegalensis Lambur and Paederus alfierii Koch were found to dominate rice fields at Kafr El-Sheikh region.

Because of the negative effect of insecticides on natural enemies populations it was pointed out that agriculture without insecticides, as in case of organic farming, has been considered to keep the natural balance, as well as preserve the native diversity in agroecosystem landscapes (Ponce et al., 2011).

The current study was carried out to: 1) survey natural enemies (parasitoids and predators) occurring in rice fields at Kafr El-Sheikh region, 2) study effect of compost adding in rice fields in enhance natural enemies and 3) monitor population densities of beneficial arthropods, as influenced by organic and chemical fertilizers, biocide and insecticides.

\section{MATERIALS AND METHODS}

The current study was carried out at the experimental farm of Rice Research and Training Center (RRTC), Sakha Agricultural Research Station, Kafr El-Sheikh Governorate during 2016 and 2017 rice growing seasons.

\section{General Procedures:}

Rice nursery (about $200 \mathrm{~m}^{2}$ ) was sown on May $5^{\text {th }}$, 2016 and 2017 with the seeds of Egyptian Hybrid one rice cultivar, and transplanting was done in one- feddan area one month later (June $5^{\text {th }}$ ) at $20 \times 20 \mathrm{~cm}$ spacing between rows and hills, with 2-3 seedlings/hill. Hand weeding was applied for weed control (manually removed throughout the rice season). No other pesticides were used during the experimental period either in the experimental field or in the surrounding area, at least $10 \mathrm{~m}$-wide. All other cultural practices were adopted as recommended. The mineral fertilizer $69 \mathrm{~kg} \mathrm{~N} /$ fed as urea $(46.5 \% \mathrm{~N})$, and 2 tons 
composted rice straw /fed. All the recommended cultural practices were followed for seedbed preparation as well as for permanent field. The decomposed compost fertilizer was applied in dry soil, then incorporated well during tillage, mineral $\mathrm{N}$ fertilizer was applied before flooding and one third at panicle initiation stage.

\section{Survey of Beneficial Arthropods:}

Throughout the period extending from May up to September, 2016, both rice nursery and permanent field were sampled to collect occurring natural enemies, using D-vac (suction) machine and pitfall traps. At each sampling date, the D-vac machine was operated for two minutes in the whole area of the nursery, and five minutes in the paddy (permanent) field. In addition, five and fifteen pitfall traps were embedded in the dikes of nursery and paddy field, respectively. The pitfall trap catch was obtained three days after fixing the traps. Pitfall trap consists of a glass jar (about one liter volume), containing water for $2 / 3$ volume of the jar, with $5 \mathrm{ml}$ of formaldehyde to prevent specimen decomposition, and $5 \mathrm{ml}$ of detergent substance to remove water surface tension, enforcing the captured arthropods to sink and be captured in the jar. One catch (by each of collecting tools) was taken from the nursery. Six samples were taken from the permanent field, beginning from two weeks after transplanting, and continued at 2-week interval up to three weeks prior to harvest. Captured arthropods were introduced into a wide - mouthed cyanide jar with a closed cap, and transferred to the laboratory. Specimens were sorted into parasitoids and predator insects and kept in glass vials containing 70\% ethyl alcohol and few drops of glycerin. Three complementary ways were used to identify and confirm identifications of collected natural enemies ; 1) Barrion and Litsinger (1994), 2) identity of collected specimens with those kept at RRTC, previously identified or confirmed by Dr. Alberto Barrion, taxonomist of International Rice Research Institute (IRRI), and 3) taxonomists of Plant Protection Research Institute, Giza, Egypt, and the third author.

3- Effect of add compost or mineral fertilizers on the population densities of natural enemies:

Because the rice straw compost act as a refuge to soil arthropods, an experiment was conducted during 2016 and 2017 rice seasons to evaluate the effect of compost and mineral fertilizers on the population densities of arthropods in rice plots. mineral fertilizers and/ or compost add inside the plots. By the beginning of heading, about two months after transplanting, the D-vac machine was installed for 60 seconds in each of rice plots fertilized by compost and mineral. Only natural enemies of relatively high density were considered (Table 3). Numbers of natural enemies, captured by the D-vac, in rice plots fertilized by compost were compared with those in mineral fertilizers (adopted as recommended).

\section{4- Influence of biocides and insecticides on target and non-target arthropods:}

Six insecticides (Table 4) were field evaluated during 2017 season for their efficiencies on target and nontarget arthropods. These treatments, as well as control, were tested in $5 \times 5 \mathrm{~m}$ field plots, planted with Egyptian Hybrid one rice cultivar. Each treatment was replicated three times in a completely randomized block design. The treatments were applied on $18^{\text {th }}$ August, 2017 coinciding with the high populations of most arthropods. Seven days after treatments, the rice plots, treated and untreated, were sampled using D-vac machine operated for 60 seconds per plot. The captured arthropods were categorized to insect pests, parasitoids and predator insects.

Analysis of variance was adopted, and means were compared using Duncan's Multiple Range Test (1955).

\section{RESULTS AND DISCUSSION}

\section{Survey of Natural Enemies: \\ Parasitoids:}

Twelve hymenopterous parasitoid species were surveyed from rice fields throughout 2016 and 2017 seasons (Table 1). The species were found belonging to Eight families; Braconidae, Dryinidae, Eulophidae, Ichneuomonidae, Mymaridae, Pteromalidae, Scelionidae and Trichgrammatidae. The latter family had the majority of surveyed parasitoids (3 species), followed by Braconidae and Mymaridae, each with two identified species. However, species related to Dryinidae, Eulophidae, Ichneuomonidae and Pteromalidae each with one identified species. Also, Claridge et al. (1999) recorded $29-91 \%$ reduction in brown planthopper populations due to potentiality of the egg parasitoids, Oligosita sp and Anagrus sp. (Marub 1993) found that the parasitoid, Trichogramma japonicum is naturally occurring in rice fields, with parasitism levels of $7.11-14.03 \%$ on eggs of yellow stem borer, Scirpophaga incertulas (Walker). In Egypt, Soliman and Ewaise (1997) and Sherif et al. (2008) recorded an efficient control (equivalent to carbofuran insecticide) of Chilo agamemnon Bles. due to the release of Trichogramma evanescens West. at the rate of 28,000 30,000 wasps / feddan. Also, Shawer et al. (2013) obtained about $63.00-65.00 \%$ reduction in Chilo agamemnon infestation in rice due to release of $T$. evanescens.

Table 1. Survey, host preference and occurrence of Hymenopterous parasitoids from rice fields Sakha, Kafr ElSheikh Governorate during 2016 and 2017 seasons

\begin{tabular}{|c|c|c|c|}
\hline Family & Species & Host & Period of occurrence \\
\hline Braconidae & Bracon hebetor Say & RSB larvae & Aug.- Sept. \\
\hline & Opius hedqusti Fischer & RLM larvae / pupae parasitoid & Jun.- Jul. \\
\hline Dry11 & Echthrodelphax migratorius Benoit & Sogatella spp. & Jul.- Sept \\
\hline Eulophidae & Tetrastichus sp. & Hyperparasitoid & May- Sept. \\
\hline Ichneuomonidae & Temelucha sp. & RSB larvae & Aug.- Sept. \\
\hline Mymaridae & $\begin{array}{l}\text { Anagrus sp } \\
\text { Gonatocerus sp. }\end{array}$ & $\begin{array}{l}\text { LH \& PH eggs } \\
\text { LH \& PH eggs }\end{array}$ & Jun.- Sept. \\
\hline Pteromalidae & Trichomalopsis sp. & Hyperparasitoid & Aug.- Sept. \\
\hline Scelionidae & $\begin{array}{l}\text { Trissolcus basalis (Woollaston) } \\
\text { Paracentrobia sp }\end{array}$ & $\begin{array}{l}\text { Nezara viridula eggs } \\
\text { LH \& PH eggs }\end{array}$ & Aug.- Sept. \\
\hline Trichogrammatidae & $\begin{array}{l}\text { Oligosita } \mathrm{sp} \\
\text { Trichogramma evanescens West. }\end{array}$ & $\begin{array}{l}\text { LH \& PH eggs } \\
\text { RSB eggs }\end{array}$ & Jul.- Sept. \\
\hline
\end{tabular}

RSB: rice stem borer RLM: rice leaf miner LH : leaf hopper PH : plant hopper 


\section{Insect predators:}

Twenty insect predator species (Table 2), related to 13 families, were surveyed. The majority of species (8) are belonging to Coleoptera, three species belonging to order Hemiptera and four to order Odonata, while two species were belonging to Hymenoptera. Rest of Orders have one identified species for each.

In similar study, (Manley 1977) found that the rove beetle, Paederus fuscipes Curt in Malaysia rice fields as a one of the most common insect predators; the adults migrate to young rice plants shortly after transplanting and remain among the tillers throughout the growing season. Also, Pantu and Litsinger (1984) reported that up to $65 \%$ of the yellow stem borer eggs were consumed by Conocephalus longipennis (de Hann).

2. Effect of fertilized by compost and recommended mineral fertilizers on population densities of natural enemies:

Data in Table (3) show that rice plots fertilized by compost contained higher populations of natural enemies than rice plots fertilized by mineral fertilizers.

Table 2. Survey and occurrence of insect predators from rice fields Sakha, Kafr El-Sheikh Governorate during 2016 and 2017 seasons

\begin{tabular}{|c|c|c|c|}
\hline Order & Family & Species & Period of occurrence \\
\hline \multirow{4}{*}{ Coleoptera } & Carabidae & Abacetus sp., Bimbidion spp., Microlestis sp & May- Sept. \\
\hline & Staphylinidae & $\begin{array}{l}\text { Paederus alfierii Koch. Paederus memnonius Erichson, } \\
\text { Philonthus spp. }\end{array}$ & May- Sept. \\
\hline & Coccinellidae & Scymnus interruptus (Goeze) & Aug.- Sept. \\
\hline & Dytiscidae & Hydaticus leander Rossi & Aug.- Sept. \\
\hline Diptera & Syrphidae & Sphorophoria scripta L. & Aug.- Sept. \\
\hline \multirow{3}{*}{ Hemiptera } & Anthocoridae & Orius albidipennis (Reuter), Orius laevigatus (Fieber) & Aug.- Sept. \\
\hline & Mesoveliidae & Mesovelia vittigera Horv & Aug.- Sept. \\
\hline & Coenagrionidae & Ischnura senegalensis (Rambur) & May- Sept. \\
\hline \multirow[t]{2}{*}{ Odonata } & Libellulidae & $\begin{array}{l}\text { Crocothemis erythraea (Brullé) } \\
\text { Brachythemis leucosticta (Burmeister) }\end{array}$ & May- Sept. \\
\hline & Aeshnidae & Hemianax ephippiger (Burmeister) & May- Sept. \\
\hline Hymenoptera & Formicidae & Monomorium sp., Solenopsis lou Forel & May- Aug. \\
\hline Neuroptera & Chrysopidae & Chrysoperla carnea Steph. & Aug.- Sept. \\
\hline Thysanoptera & Aelothripidae & Aeolothrips sp. & May- Jul. \\
\hline
\end{tabular}

Table 3. Population densities of natural enemies in rice plots fertilized by compost and recommended mineral fertilizers at Sakha, Kafr El-Sheikh Governorate during 2016 and 2017 seasons

\begin{tabular}{lccc}
\hline \multirow{2}{*}{ Natural Enemies } & \multicolumn{2}{c}{ Numbers in D-vac catch (operated for 60 seconds / plot) } \\
\cline { 2 - 4 } Compost & Mineral & Mineral / Compost \% \\
\hline Parasitoids & 12.25 & 4.00 & 32.65 \\
Bracon hebetor Say (Braconidae) & 19.00 & 12.25 & 64.47 \\
Oligosita sp. (Trichogrammatida) & 5.25 & 1.00 & 19.05 \\
Paracentrobia sp. (Trichogrammatidae) & 16.25 & 6.00 & 36.92 \\
Opius spp. (Braconidae) & 65.50 & 28.50 & 40.46 \\
Trichogramma evanescens West (Trichogrammatidae) & & & 52.17 \\
Insect Predators & 23.00 & 12.00 & 52.74 \\
Ischnura senegalensis Rambur (Coenagrionidae) & 36.50 & 19.25 & 52.94 \\
Paedrerus alfierii Koch (Staphylindae) & 21.25 & 11.25 & 51.35 \\
Philonthus spp (Staphylindae) & 18.50 & 9.50 & \\
Bimbidion spp. (Carabidae) & &
\end{tabular}

The increase in parasitoid populations ranged between 19.05\% (Paracentrobia sp.) and $64.47 \%$ (Oligosita sp.). The insect predatory populations were increased from $51.35 \%$ (Bimbidion spp., Carabidae) to $52.94 \%$ (Philonthus spp., Staphylindae ). These differences could be interpreted as rice plots fertilized by compost may cause rapid increase in the populations of detritivores (such as collembolans and ephydrid flies) and plankton feeders (such as mosquito larvae and chironomid midge larvae), which are important alternative prey for insect predators during early crop session when potential prey items are not present (Settle et al., 1996). Also, Afun et al. (1999) indicated that staphylinid beetles were more abundant in rice plots with supplementary weed mulch than in plots with removed mulch.

3. Influence of bio and chemical insecticides on target and non-target insects:

Insect pests:

Data in Table (4) show the effectively of bio and chemical insecticides on insect pests common in rice fields. Achook (Azadirachta indica) (Neem) application reduced insect population from 33.30 to $57.32 \%$. Satisfactory control was obtained concerning Nezara viridula and Hydrellia prosternalis, with values of 57.32 and $54.82 \%$ population reductions, respectively. Dipel (B. thuringiensis var kurstaki) and Biofly (Beauveria bassiana) were relatively less effective against the considered insect pests compared to Achook, with reductions of $10.73-48.74 \%$ for the former biocide and $10.00-39.82 \%$ for the latter one. Tracer (Spinosad) gave poor results against leaf hopper, plant hopper, and Chilo agamemnon, but moderate results against the other insect pests. The two chemical insecticides; Radiant (spinetoram) and Furadan (carbofuran) were the highest effective compounds against insect pests; most population reductions exceeded $80.00 \%$, and were $100.00 \%$ in some cases.

In another study, Abudulai et al., (2004) reported that neem may not interfere with the predation on Nezara viridula eggs. Thus, neem could be an important component of integrated pest management. Also, 
(Sagheer et al. 2008) found that infestation of rice plants by the leaf folder was highest in the control plots, but reached minimum with application of $B t$ followed by neem.

Table 4. Effect of organic and chemical insecticides on populations of some rice insect pests, 2017 season

\begin{tabular}{|c|c|c|c|c|c|c|c|c|c|c|c|}
\hline \multirow[t]{2}{*}{$\begin{array}{l}\text { Trade name and } \\
\text { Common name }\end{array}$} & \multirow[t]{2}{*}{$\begin{array}{c}\text { Rate/ } \\
\text { feddan }\end{array}$} & \multicolumn{2}{|c|}{$\begin{array}{c}\text { LH \& P H* } \\
\text { (adult \& } \\
\text { nymph) }\end{array}$} & \multicolumn{2}{|c|}{$\begin{array}{l}\text { Chironomus } \\
\text { sp (adult) }\end{array}$} & \multicolumn{2}{|c|}{$\begin{array}{l}\text { Hydrellia } \\
\text { prostenalis } \\
\text { (adult) }\end{array}$} & \multicolumn{2}{|c|}{$\begin{array}{l}\text { Nezara viridula } \\
\text { (adult \& } \\
\text { nymph) }\end{array}$} & \multicolumn{2}{|c|}{$\begin{array}{c}\text { Chilo } \\
\text { agamemnon } \\
\text { (adult) }\end{array}$} \\
\hline & & No & Red \% & No & $\operatorname{Red} \%$ & No & Red \% & No & Red \% & No & Red \% \\
\hline Control & ---- & $151.50 \mathrm{a}$ & - & $80.83 \mathrm{a}$ & - & $60.83 \mathrm{a}$ & - & $25.00 \mathrm{a}$ & 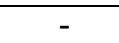 & 15.50 & - \\
\hline $\begin{array}{l}\text { Achook } 0.15(\text { Neem }) \mathrm{EC} \\
\text { Azadirachta indica }\end{array}$ & $750 \mathrm{ml}$ & $75.83 \mathrm{~d}$ & 51.83 & $50.50 \mathrm{c}$ & 40.26 & $30.50 \mathrm{~b}$ & 54.82 & $16.17 \mathrm{c}$ & 57.32 & $12.17 \mathrm{ab}$ & 33.30 \\
\hline $\begin{array}{l}\text { Dipel 6.4 DF } \\
\text { Bacillus thuringiensis }\end{array}$ & $300 \mathrm{~g}$ & $135.83 \mathrm{~b}$ & 10.73 & $65.50 \mathrm{~b}$ & $20 . .35$ & $30.50 \mathrm{~b}$ & 48.74 & $20.83 \mathrm{bc}$ & 38.68 & $12.17 \mathrm{ab}$ & 33.30 \\
\hline $\begin{array}{l}\text { Biofly } \\
\text { Beauveria bassiana }\end{array}$ & $250 \mathrm{ml}$ & $101.83 \mathrm{c}$ & 39.02 & $50.83 c$ & 39.82 & $39.17 b$ & 35.53 & $24.17 \mathrm{ab}$ & 25.32 & $14.50 \mathrm{a}$ & 10.00 \\
\hline $\begin{array}{l}\text { Tracer 24 SC } \\
\text { Spinosad }\end{array}$ & $50 \mathrm{ml}$ & $115.50 \mathrm{c}$ & 24.66 & $46.17 \mathrm{c}$ & 46.01 & $39.17 b$ & 39.15 & $20.83 b c$ & 38.68 & $14.50 \mathrm{a}$ & 10.00 \\
\hline $\begin{array}{l}\text { Radiant } 12 \mathrm{SC} \\
\text { Spinetoram }\end{array}$ & $120 \mathrm{ml}$ & $36.83 \mathrm{e}$ & 78.54 & $25.50 \mathrm{~d}$ & 73.45 & $15.50 \mathrm{c}$ & 81.93 & $0.00 \mathrm{~d}$ & 100.00 & $7.50 \mathrm{c}$ & 80.00 \\
\hline $\begin{array}{l}\text { Furadan } 10 \mathrm{G} \\
\text { Carbofuran }\end{array}$ & $6 \mathrm{~kg}$ & $45.83 \mathrm{e}$ & 72.38 & $16.50 \mathrm{e}$ & 85.40 & $16.50 \mathrm{c}$ & 80.12 & $0.00 \mathrm{~d}$ & 100.00 & $8.53 \mathrm{bc}$ & 66.70 \\
\hline
\end{tabular}

Means followed by the same letter are not significantly at the $5 \%$ level.

* Leaf hoppers and plant hoppers

Parasitoids:

Neem, Dipel and biofly were hazardous (52.64 $93.18 \%$ population reduction) to all parasitoids considered in the current investigation (Table 5). In most cases, they killed almost $80 \%$ of different parasitoid species. Also, the two insecticides; Radiant and Furadan were highly toxic $(84.21-100.00 \%)$ to these parasitoids. Relatively, Tracer was less lethal (25.00-78.93\% population reduction) to the evaluated parasitoids.
(Raguraman and Singh 1999) found that antifeedancy of neem on parasitoids is clearly seen when these parasitoids were subjected to a substrate treated with neem products. Also, Biondi et al., (2012) recommended caution in the use of spinosad because of its negative side effects to many non-target species, including hymenopterous parasitoids. Liu and Zhang (2012) reported that indoxacarb residues caused less than $20 \%$ mortality to adults of the hymenopteran parasitoids; Trichogramma pretiosum Riley and Trichogramma brassicae Bezdenko.

Table 5. Effect of organic and chemical insecticides on populations of common parasitoids in rice fields, 2017 season

\begin{tabular}{|c|c|c|c|c|c|c|c|c|c|c|c|}
\hline \multirow{2}{*}{$\begin{array}{l}\text { Trade name and } \\
\text { Common name }\end{array}$} & \multirow[t]{2}{*}{$\begin{array}{c}\text { Rate/ } \\
\text { feddan }\end{array}$} & \multicolumn{2}{|c|}{ Anagrus sp } & \multicolumn{2}{|c|}{$\begin{array}{l}\text { Bracon } \\
\text { hebetor }\end{array}$} & \multicolumn{2}{|c|}{ Oligosita sp } & \multicolumn{2}{|c|}{$\begin{array}{c}\text { Opius } \\
\text { hedqusti }\end{array}$} & \multicolumn{2}{|c|}{$\begin{array}{c}\text { Trichogramma } \\
\text { evanescens }\end{array}$} \\
\hline & & No & Red \% & No & Red \% & No & Red \% & No & $\operatorname{Red} \%$ & No & Red \% \\
\hline Control & ---- & $16.00 \mathrm{a}$ & - & $13.77 \mathrm{a}$ & - & $27.10 \mathrm{a}$ & - & $19.67 \mathrm{a}$ & - & $61.67 \mathrm{a}$ & - \\
\hline $\begin{array}{l}\text { Achook } 0.15(\text { Neem }) \mathrm{EC} \\
\text { Azadirachta indica }\end{array}$ & $750 \mathrm{ml}$ & $3.43 \mathrm{c}$ & 85.44 & $3.43 \mathrm{c}$ & 81.61 & $4.77 \mathrm{bc}$ & 85.88 & $3.00 \mathrm{c}$ & 86.37 & $11.67 \mathrm{~b}$ & 81.17 \\
\hline $\begin{array}{l}\text { Dipel 6.4 DF } \\
\text { Bacillus thuringiensis }\end{array}$ & $300 \mathrm{~g}$ & $3.77 \mathrm{c}$ & 83.31 & $5.10 \mathrm{bc}$ & 68.43 & $4.77 \mathrm{bc}$ & 85.88 & $3.00 \mathrm{c}$ & 86.37 & $9.67 \mathrm{c}$ & 84.70 \\
\hline $\begin{array}{l}\text { Biofly } \\
\text { Beauveria bassiana }\end{array}$ & $250 \mathrm{ml}$ & $0.00 \mathrm{c}$ & 100.00 & $7.10 \mathrm{~b}$ & 52.64 & $4.10 \mathrm{bc}$ & 88.46 & $2.00 \mathrm{c}$ & 93.18 & $5.67 \mathrm{c}$ & 91.76 \\
\hline $\begin{array}{l}\text { Tracer 24 SC } \\
\text { Spinosad }\end{array}$ & $50 \mathrm{ml}$ & $13.10 \mathrm{~b}$ & 25.00 & $3.77 \mathrm{c}$ & 78.93 & $7.77 \mathrm{~b}$ & 74.35 & $7.33 \mathrm{~b}$ & 56.85 & $13.00 \mathrm{~b}$ & 78.82 \\
\hline $\begin{array}{l}\text { Radiant } 12 \mathrm{SC} \\
\text { Spinetoram }\end{array}$ & $120 \mathrm{ml}$ & $3.43 \mathrm{c}$ & 85.44 & $3.10 \mathrm{c}$ & 84.21 & $0.00 \mathrm{c}$ & 100.00 & $3.00 \mathrm{c}$ & 86.37 & $3.33 \mathrm{~d}$ & 95.89 \\
\hline $\begin{array}{l}\text { Furadan } 10 \mathrm{G} \\
\text { Carbofuran }\end{array}$ & $6 \mathrm{~kg}$ & $0.00 \mathrm{c}$ & 100.00 & $3.10 \mathrm{c}$ & 84.21 & $0.00 \mathrm{c}$ & 100.00 & $0.00 \mathrm{c}$ & 100.00 & $3.00 \mathrm{~d}$ & 96.47 \\
\hline
\end{tabular}

Means followed by the same letter are not significantly at the $5 \%$ level.

\section{Insect Predators:}

The evaluated bio and chemical insecticides were always highly toxic to Ischnura sensgalensis (Table 6). Tracer was relatively less toxic to all predators, while both Dipel and Biofly were moderately hazardous. As in the case of insect pests and parasitoids, both chemical insecticides; Radiant and Furadan were the highest toxic compounds against the considered insect predators.

In other study, Galvan et al. (2006) reported that the conventional insecticide, indoxacarb caused close to $100 \%$ mortality to $3^{\text {rd }}$ instar of the lady beetle Harmonia axyridis Pallas. Also, Thungrabeab and Tongma (2007) found that Beauveria bassiana (Balsamo) Vuillemin was non-pathogenic to natural enemies and beneficial soil insects while Meterhizium anisopliae Metsch had pathogenecity to Chrysoperla carnea and Dicyphus tamaninii (Hemiptera: Miridae).

The microorganism-derived insecticide, emamectin benzoate induced high motality to Orius insidiosus Say (Hemiptera: Anthocoridae) (Studebaker and Kring 2013). Martinou et al., (2014) studied the side effect of traditional insecticides compared to biopesticides on the predator, Mcrolophus pygmaeus (Hemiptera: miridae) attacking a variety of insect pests, from which is Tuta absoluta and whiteflies. The biocides caused $25-30 \%$ mortality to the predator, and were classified as harmless according to the international organization for biological control, while 
traditional insecticides caused $80-100 \%$ mortality to the predator, and were classified as harmful. Martinou et al., (2014) suggested that the safety of microorganism derived biocide, emamectin benzoate seems to be species dependent, because this compound was harmful to the mirid predator, $M$. pygmaeus but harmless to the anthocorid predator, $O$. insidiosus.

Table 6. Effect of organic and chemical insecticides on populations of common insect predators in rice fields, 2017 season

\begin{tabular}{|c|c|c|c|c|c|c|c|c|c|c|c|}
\hline \multirow{2}{*}{$\begin{array}{l}\text { Trade name and } \\
\text { Common name }\end{array}$} & \multirow[t]{2}{*}{$\begin{array}{l}\text { Rate/ } \\
\text { feddan }\end{array}$} & \multicolumn{2}{|c|}{$\begin{array}{c}\text { Ischnura } \\
\text { sensgalensis }\end{array}$} & \multicolumn{2}{|c|}{$\begin{array}{c}\text { Scymnus } \\
\text { interruptus }\end{array}$} & \multicolumn{2}{|c|}{$\begin{array}{l}\text { Paederus } \\
\text { alfierii }\end{array}$} & \multicolumn{2}{|c|}{ Philonthus spp } & \multicolumn{2}{|c|}{$\begin{array}{c}\text { Sphorophoria } \\
\text { scripta }\end{array}$} \\
\hline & & No & Red \% & No & Red \% & No & Red \% & No & Red \% & No & Red \% \\
\hline Control & ---- & $58.67 \mathrm{a}$ & - & $14.00 \mathrm{a}$ & - & $40.00 \mathrm{a}$ & - & $39.33 \mathrm{a}$ & - & $17.00 \mathrm{a}$ & - \\
\hline $\begin{array}{l}\text { Achook } 0.15(\text { Neem }) \mathrm{EC} \\
\text { Azadirachta indica }\end{array}$ & $750 \mathrm{ml}$ & $24.00 \mathrm{~b}$ & 65.82 & $10.33 \mathrm{bc}$ & 45.88 & $26.33 \mathrm{~b}$ & 35.97 & $18.33 \mathrm{~b}$ & 54.79 & $10.00 \mathrm{a}$ & 43.75 \\
\hline $\begin{array}{l}\text { Dipel 6.4 DF } \\
\text { Bacillus thuringiensis }\end{array}$ & $300 \mathrm{~g}$ & $20.33 \mathrm{bc}$ & 72.79 & $10.67 \mathrm{~b}$ & 41.63 & $18.67 \mathrm{~cd}$ & 56.13 & $5.67 \mathrm{c}$ & 33.66 & $4.00 \mathrm{a}$ & 81.25 \\
\hline $\begin{array}{l}\text { Biofly } \\
\text { Beauveria bass }\end{array}$ & $250 \mathrm{ml}$ & $14.67 \mathrm{~cd}$ & 83.54 & $9.67 \mathrm{bcd}$ & 54.13 & $16.00 \mathrm{de}$ & 63.16 & $3.67 \mathrm{c}$ & 93.03 & $6.33 \mathrm{a}$ & 66.69 \\
\hline $\begin{array}{l}\text { Tracer 24 SC } \\
\text { Spinosad }\end{array}$ & $50 \mathrm{ml}$ & $18.0 \mathrm{bcd}$ & 77.22 & $9.33 \mathrm{bcd}$ & 58.38 & $21.33 \mathrm{c}$ & 49.13 & $24.33 \mathrm{~d}$ & 39.13 & $6.67 \mathrm{a}$ & 64.56 \\
\hline $\begin{array}{l}\text { Radiant } 12 \text { SC } \\
\text { Spinetoram }\end{array}$ & $120 \mathrm{ml}$ & $17.00 \mathrm{~cd}$ & 79.11 & $8.00 \mathrm{~cd}$ & 75.00 & $3.33 \mathrm{e}$ & 96.50 & $2.67 \mathrm{c}$ & 95.64 & $3.00 \mathrm{a}$ & 87.50 \\
\hline $\begin{array}{l}\text { Furadan } 10 \mathrm{G} \\
\text { Carbofuran }\end{array}$ & $6 \mathrm{~kg}$ & $11.67 \mathrm{~d}$ & 89.23 & $7.67 \mathrm{~d}$ & 79.13 & $3.33 \mathrm{e}$ & 96.50 & $3.00 \mathrm{c}$ & 94.78 & $5.33 \mathrm{a}$ & 72.94 \\
\hline
\end{tabular}

Means followed by the same letter are not significantly at the $5 \%$ level.

As a conclusion, the results of the current study revealed the occurrence of a diversified fauna of beneficial insects. Fortunately, add of rice straw compost enhance many natural enemies specially ground insects and in the other side unfortunately, these natural enemies are greatly impaired with insecticide application. An important topic should be intensively investigated, that is the adverse effects of biocides on these natural enemies, because the common theory is that biocides are usually safe to such enemies, which was not clear in this study.

\section{REFERENCES}

Abbas, M. S. (1998). Mass production and utilization of Trichogramma evanescens as a biocontrol agent against tomato fruit worm, Heliothis armigera in Egypt. Egg parasitoids, Cali. Colombia, March. Mitt. Biol. Bundesssntslat, Berlin Dahlem, H. 356.

Abudulai, M., B. M. Shepard and P. L. Michell (2004). Effects of neem (Azadirachta indica A. Juss) on predators of Nezara viridula (L.) (Hemiptera: Heteroptera: Pentatemidae). J. Agric. Urban Entomol., 21 (1): 9-13.

Afun, J.V. K., D. E. Johnson and A. Russell- Smith (1999). The effect of weed residue management on pests, pest damage, predators and crop yield in Upland Rice in Cote d' Ivoire. Biological Agriculture and Horticulture: An International Journal for Sustainable Production Systems. 17(1): 47- 58.

Anonymous (2002). Control rice stem borer-use Trichogramma japonicum. Report of Department of Agriculture, Regional Field Unit, No. Northen Mindano, Phillipines.

Badr, A. M. (2008). Organic rice production under different organic treatments. M.Sc. Thesis, Fac. Agric. Kafrelsheikh University, Egypt. 103 pp.

Barrion, A. T. and J. A. Litsinger (1994). Taxonomy of rice insect pests and their arthropod parasites and predators, pp. 13 - 362. In : Heinrichs, E. A. (ed). Management of Rice Insects. Wiley Eastern Limited, New Delhi, 779 pp.
Bigler, F. (1986). Mass production of Trichograma maidis Pint, et Voeg- and its field application against Ostrinia nubilalis Hbn. In Switzerland. Journal of Applied Entomology, 101(issue 1-5): $23-29$.

Biondi, A., V. Mommaerts, G. Smagghe, E. Vinuela, L. Zapppala and N. Desneux (2012). The non- target impact of spynosyns on beneficial arthropods. Pest Manag. Sci., 68: 1523-1536.

Claridge, M. F., J. C. Morgan, A. E. Steenkiste, M. Iman and D. Damyanti (1999). Seasonal patterns of egg parasitism and natural biological control of rice brown planthopper in Indonesia. Agricultural and forest Entomology, 1(4): 297304.

Duncan, D. B. (1955). Multiple Range and Multiple F Test. Biometrics, 11: 1-42.

Galvan, T.L.; R.L. Koch and W.D. Hutchison (2006). Toxicity of indoxacarb and spinosad to the multicolored Asian lady beetle, Harmonia axyridis (Coleoptera: Coccinellidae) via three routes of exposure. Pest Manag. Sci., 62(9): 797-804.

Gotoh, S; H. Koga and S.I. Ono (1984). Effect of longterm application of organic residues on the distribution of organic matter and nitrogen in some rice soil profiles. Soil Sci. and Plant-Nutr., 30(3):273-285.

Heckman, C.W. (1979). Rice field ecology in North East Thailand. Monogr. Biol. 4: 228.

Heckman, J. (2006). A history of organic farming: Transitions from Sir Albert Howard's war in the soil to USDA National Organic Program. Renewable Agriculture and Food Systems 21:143-150.

Hendawy, A.S. (2001). Egg and nymphal parasitoids of rice leafhoppers and planthoppers in Egypt. Proceedings of the First Conference of Safe Alternatives Pesticides for Pest Management. Fac. Agric. Assiut Univ., Egypt, 28-29, 2001. pp: 251-260. 
Heong, K. L., Aquino, G. B. \& Barrion, A. T. (1991). Arthropod community structures of rice ecosystems in the Philippines. Bulletin of Entomological Research 81: 407-416.

Liu, T.X. and Y. Zhang (2012). Side effects of two reduced-risk insecticides, endoxacarb and spinosad, on two species of Trichogramma (Hymenoptera: Trichogrammatidae) on cabbage. Ecotoxicology, 21: 2254-2263.

Manley, G. V. (1977). Paederus fuscipes (Gl: Staphylinidae): A predators of rice fields in west Malaysia. Entemephaga, 22(1): 47 - 59.

Martinou, A. F., N. Seraphides and M. C. Stavrinides (2014). Lethal and behavioral effects of pesticides on the insect predator, Macrolophus Pygmaeus. Chemosphere, 96: 167- 173.

Marub, F. (1993). YRSB eggs parasitoid potential to different rice varieties in an IPM. Ilum Pertania, 5 (3): $645-656$.

Pantu, P. C. and J. A. Litsinger (1984). A meadow grasshopper, Gnocephalus longipennis (Orthoptera: Tettigoniidae) predator of rice yellow stem borer (YSB) egg masses. Int. Rice Res. Newsl., 9(4) : 13.

Ponce, C., C. Bravo, D. G, Leon, M. Magana and J. C. Alonso (2011). Effects of organic farming on plant and arthropod communities: A case study in Mediterranean dry land cereal. Agriculture, Ecosystem, Environment, 141 : 193 - 201.

Raguraman, S. and R. R. Singh (1999). Biological effects of neem ( Azadirachta indica) seed oil on egg parasitoid, Trichogramma Chilonis. Journal of Economic Entomology, 92 (6): 1274 - 1280.

Sagheer, M.; M. Ashral, M. Hasan, S. A. Rana (2008). Integration of some biopesticides and Trichogramma Chilonis for the sustainable management of rice leaf folder, Cnaphalococis medinalis (Lepidoptera: Pyralidae. Pak. J. Agric. Sci., 45 (1): $69-74$.
Settle, W.H., Ariawan, H., Astuti, T.E., Cahyana, W., Hakim, L.A., Hindayana, D. and Lestari, S.A., (1996). Managing tropical rice pests through conservation of generalist natural enemies and alternative prey. Ecology, 77: 1975-1988.

Shawer, M. B. , F. M. El-Agamy, A. S. Hendawy and E. A. Refaei (2013). Effect of Trichogramma evanescens West. release in rice stem borer control. J. Plant Prot. and Path., Mansoura Univ., 4(3): 261 264.

Sherif, M. R., A. S. Hendawy and M. M. El-Habashy (2008). Utilization of Trichogramma evanescens West. for controlling rice stem borer, Chilo agamemnon Bles. in rice fields in Egypt. Egypt. J. Biol. Pest Control, 18 (1): 11-18.

Soliman, A. M. and M. A. Ewaise (1997). Evaluation of Trichogramma evanescens parasitoid as compared with recommended Furadan insecticide against Chilo agamemnon Bles. in rice field. Egyptian Journal of Agricultural Research, 75 (1): 105 - 110

Studebaker, G. and T. Kring (2013). Effects of insecticides on Orius insidiosus (Hemiptera: Anthocoridae), measured by field, greenhouse and Petri dish bioassays. Fla. Entomol., 86: 178-195.

Thungrabeab, M. and S. Tongma (2007). Effect of entomopathogenic fungi, Beauveria bassiana (Balsam) and Metarhizium anisopliae (Metsch) on non target insects. Knitl. Sci. Tech. J., 7(1): 8-12.

Toledo, A. V.; A. M. M. de Remes lenicov and C. C. Lopez Lastra (1990). Histopathology caused by the entomopathogeni Fungi, Beauveria bassiana and Metarhizium anisopliae, in the adult planthopper, Peregrinus maidis, a maize virus vectr. Journal of Insect Science, 10: 1 - 10.

YungYu, C. (2005). Effect of application of different types of organic compost on rice growth under laboratory conditions. Soil Sci. and Plant Nutr. 51(3):443-449.

\section{تأثثر المبيدات الحيوية و المبيدات الحشرية و الكمبوست والأسمدة المعدنية على وفرة الطفيليات والمفترسات الحشرية

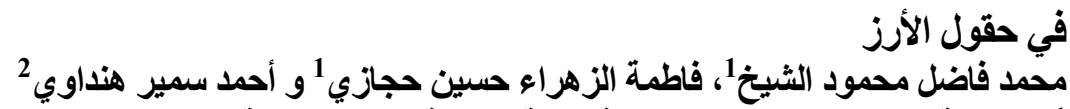

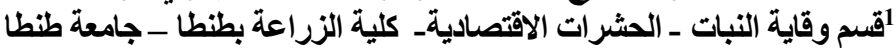

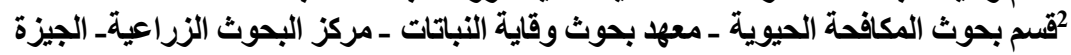

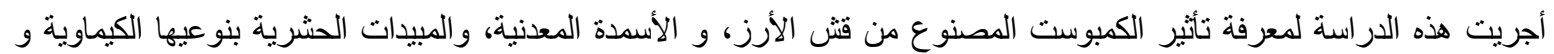

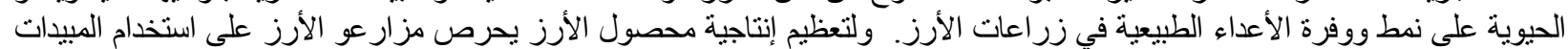

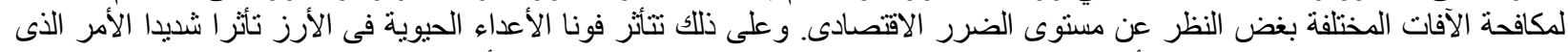

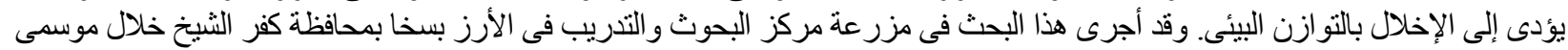

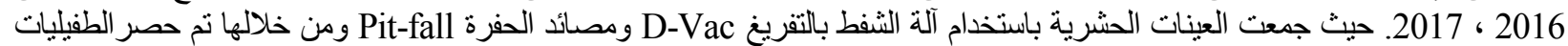

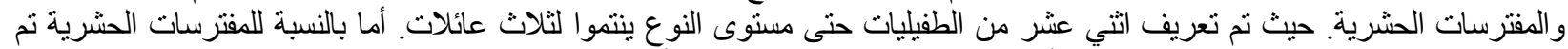

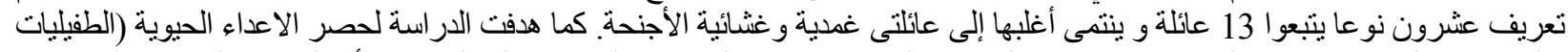

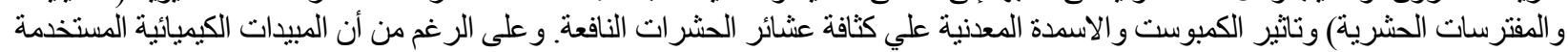

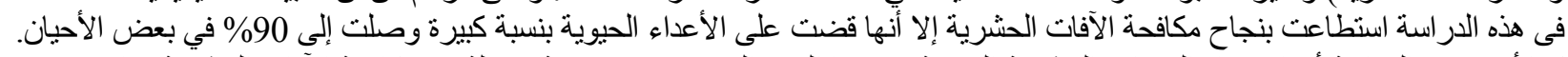

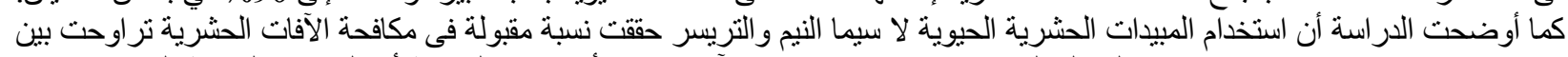

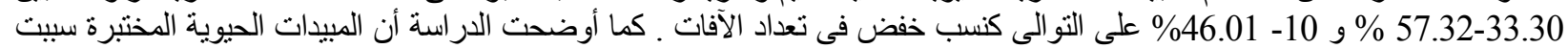

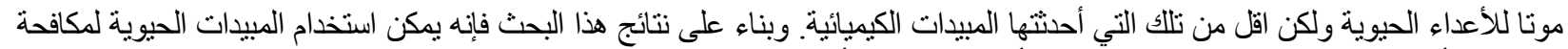

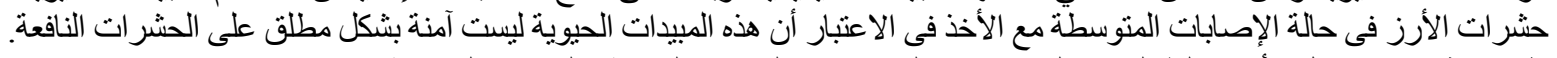

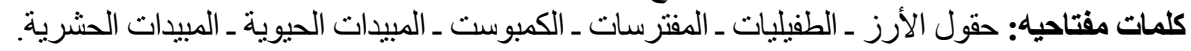

